\title{
THE FISH AND FISHERIES OF THE LOWER VOLTA MANGROVE SWAMPS IN GHANA
}

\author{
Hederick R. Dankwa ${ }^{1}$ and Chris Gordon ${ }^{2}$ \\ ${ }^{1}$ Water Research Institute, CSIR, Box 38, Achimota Ghana. \\ ${ }^{2}$ Volta Basin Research Project, University of Ghana, \\ P.O. Box LG 209, Legon Ghana \\ e-mail: chrisgordon@ighmail.com
}

\begin{abstract}
The fish and fisheries of the Lower Volta mangrove swamps were studied to provide data for the formulation of management strategies to sustain utilisation of the fishery resources in the area. Thirty-eight finfishes and 14 shellfishes species were encountered during the study period. Gerres melanopterus, Clarias anguillaris, Liza falcipinnis, Mugil curema and Sarotherodon melanotheron were the most abundant fin fish species constituting 20.2\%, 18.7\%, 9.7\%, 9.6\% and $8.5 \%$ respectively of the total catch. Areas with more extensive mangrove cover had higher species diversity than areas with sparse or no mangrove vegetation. The length frequency distribution of all the species considered indicated a higher proportion of juveniles in the catch emphasising the nursery role of the study area. A conservative estimate indicated fish yield of between 450 and 500 Mt $y^{-1}$ valued at about US\$400,000 - 450,000 from the area. Factors affecting fish yield and recommendations for sustainable development and exploitation of the fishery resource are discussed, as part of an integrated approach for the management of the area.
\end{abstract}

\section{INTRODUCTION}

The value of mangrove ecosystems and the wide variety of useful functions that they perform have been well documented (Turner, 1977; Robertson, 1986; Singh, 1987; Bailey, 1988). For marine fishes especially, and many aquatic organisms, mangrove provide spawning, nursery and forage grounds for post larvae and juveniles (Weistein, 1979; Shenker and Dean, 1979; Robertson and Duke, 1987; Sasekumar et al., 1992).

The dependence of juveniles of many marine species on mangrove ecosystems is attributed to their higher productivity as compared to adjacent marine areas (Robertson, 1986). Mc Hugh (1966) estimated that approximately two thirds of commercially important fishes depend on estuarine habitats for the growth of their young. In fact, good correlation has been found between fish and shrimp yields and the area of mangroves adjacent to identified fishing grounds (Brusher, 1974; Mac Nae, 1974; Turner, 1977; Sasekumar and Chong, 1987). Mangroves also serve a vital link for anadromous and catadromous species that need both fresh and marine environments to complete their life cycle.
In spite of their unique physical, biological and economic functions, mangroves and other coastal wetlands are being destroyed with little regard for the consequences. The Lower Volta area in Ghana is no exception. The concern for mangrove loss prompted the implementation of the Lower Volta Mangrove Project (LVMP).

The LVMP aimed at collecting base line information that could help in the formulation of management strategies to ensure sustainable utilisation of the mangrove resource for the benefit of the local people who depend on them. This study provides baseline information on the fishery component of the project.

\section{MATERIALSAND METHODS}

\section{Study Area}

The study area covered the mangroves at the Volta estuary including the Aglor and Agbatsivi lagoons and associated brackish-fresh water channels. For convenience the area was divided into seven stations (Fig. 1). All the stations, except Stations 1 and 7, were fringed with varying degrees of mangrove cover with canopies reaching above $10 \mathrm{~m}$ in 


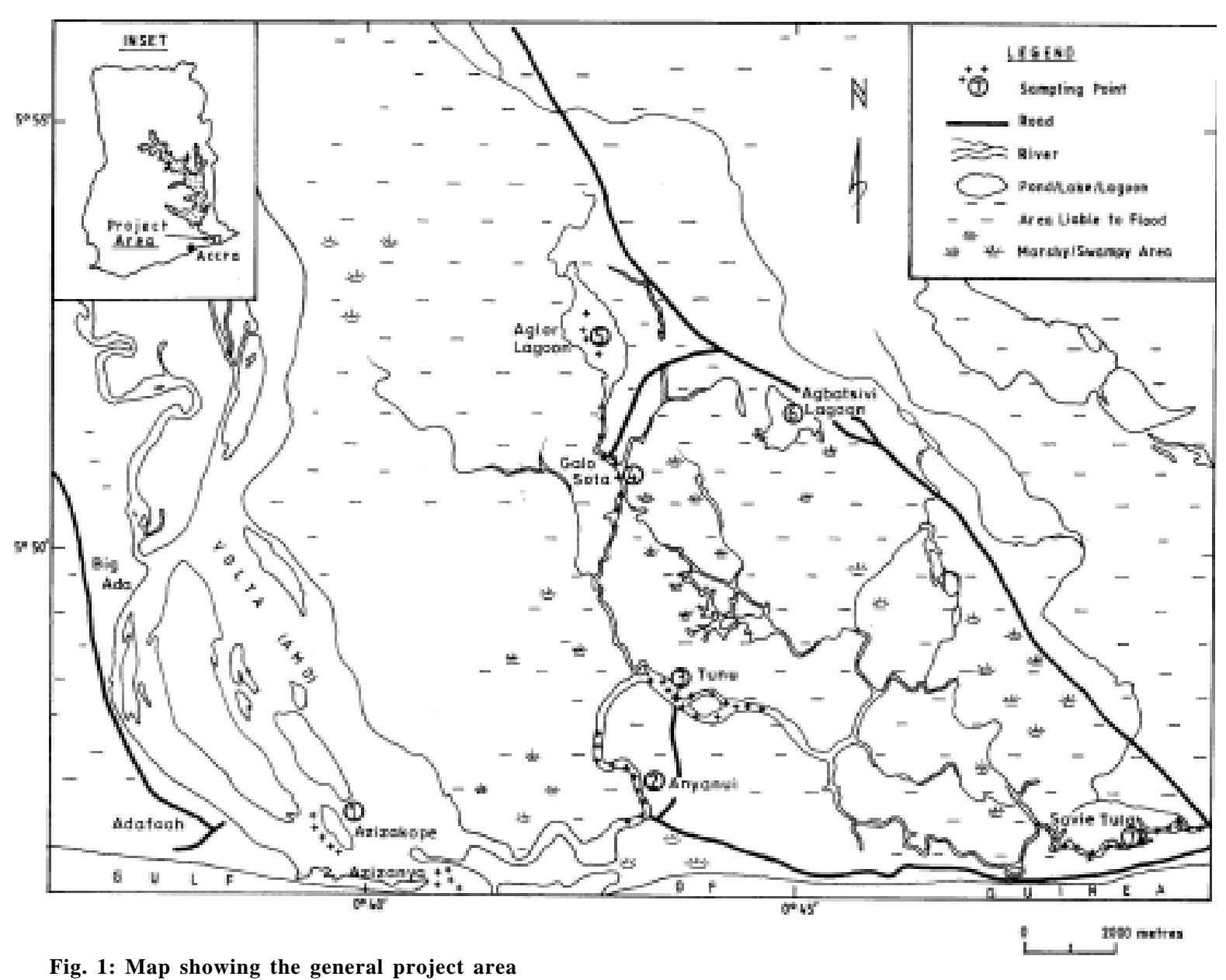

some places. However, the mangrove vegetation in some parts had been lost due to over exploitation. Apart from Station 6, all the other stations were tidal with a range of about $1.0 \mathrm{~m}$.

\section{Fish Sampling Methods}

Fish samples were obtained at Stations 1, 2, 3, 4 and 7 by deployment of:

a) a battery of multifilament gill nets consisting two nets each of net mesh sizes 12.5, 15.0, 17.5, 20.0, 30.0 and $40.0 \mathrm{~mm}$ (stretched mesh). Each net has a surface area of $50 \mathrm{~m}^{2}$

b) a battery of monofilament gill nets consisting of one each of net mesh sizes 50.0, 60.3, 75.0 mm (stretched mesh). Each has a surface area of $100 \mathrm{~m}^{2}$.

c) cast net with 4-m diameter and stretched net mesh size of $10 \mathrm{~mm}$. d) bag seine measuring $50 \mathrm{~m}$ long $\mathrm{x} 2 \mathrm{~m}$ high with stretched net mesh size of $15 \mathrm{~mm}$ for the wings and $10 \mathrm{~mm}$ for the bag.

All gill nets were set over night (i.e, from $1800 \mathrm{~h}$ to $0600 \mathrm{~h}$ ). Scoop nets and small seine nets were deployed in small pools where mangrove prop roots made deployment of other gears impossible. Catches of local fishermen were inspected and where possible samples were purchased to augment experimental fishing. During the study period, which was between April and September 1997, each station was sampled on three occasions.

Observations were also made with respect to fishing gears and methods used by the local fishermen. Other related information concerning practices in the fishing industry in the study area was obtained by interacting with local fishermen and opinion leaders in a series of focussed interviews. 


\section{Treatment of fish samples}

Fishes sampled from each station were individually identified in the field using identification keys of Schneider (1990) and Lévèque et al., (1990, 1992). The length and weight of each individual was recorded to the nearest $0.1 \mathrm{~mm}$ and gram respectively. The sex and stage of gonad development of each individual was determined after the keys of Lavaetsu (1965).

\section{Analysis of data}

Fish species and family composition in terms of number and weight per each station were estimated by pooling samples from all gears deployed at a station. Data obtained from each station was pooled to obtain information on fish catches from the study area. The length-frequency distribution of species occurring in appreciable numbers was plotted to determine size composition for each species. A number of ecological indices were used to describe the structure of the community and also to enable comparisons to be made between the stations. These were Margalef's index (D) for species richness (Margalef, 1968), ShannonWeiner's index (H') of heterogeneity or diversity (Shannon and Weiner, 1968), Pieliou's index (E) for evenness (Pielou, 1969).

\section{RESULTS}

\section{Fin fishes}

Finfish species encountered during the study is presented in Table 1. Fishes identified belonged to 23 families, 30 genera and 38 species. The species consisted of 10 fresh water, 8 brackish water and 20 marine species.

\section{Distribution}

Six species: Chrysichthys nigrodigitatus, Sarotherodon melanotheron, Liza falcipinnis, Dormitator lebretonis, Gerres malanopterus and Citharichthys stampflii, were the most widely spread (Table 1). Generally, the marine species were confined to the southern section of the study area (Stations $2 \& 3$ ) while the brackish water species showed an expected wider distribution.

Fresh water species dominated catches in the upper reaches of the study area except a few e.g., Chrysichthys nigrodigitatus, which was also caught close to the mouth of the estuary. The most common finfishes found within the mangrove were the gobiids, Periophthalmus papilio, Porogibious schlegelii and Dormitator lebretonis, the eleotrid, Eleotris senegalensis and the cichlid, Sarotherodon melanotheron.

\section{Catch Composition}

The percentage composition of species in terms of weight and number is presented in Fig. 2. Considering the whole area, Gerres melanopterus was the most dominant species during the study period. It constituted, in terms of number, $20.2 \%$ of the total catch. This was followed (in decreasing order of importance), by Clarias anguillaris $18.7 \%$, Liza falcipinnis 9.7\%, Mugil curema 9.6\% and Sarotherodon melanotheron $8.5 \%$. By weight however, Heterotis
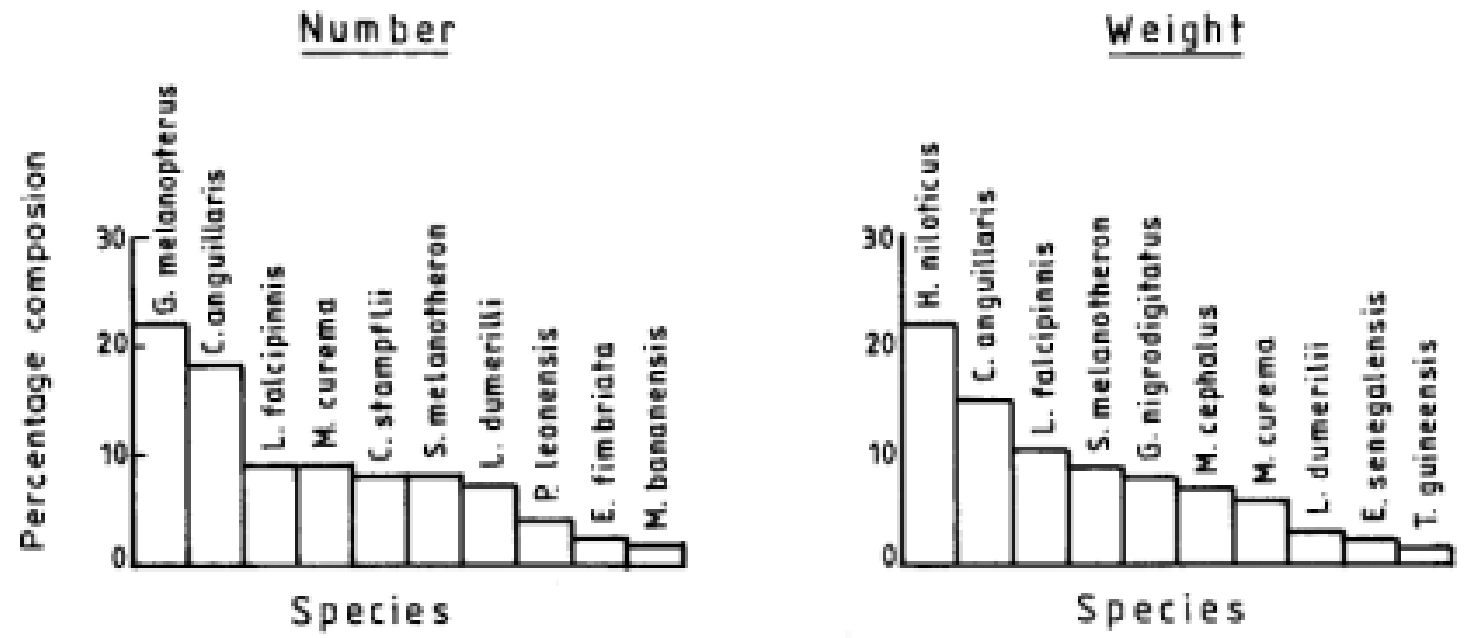

Fig. 2: Percentage composition of most dominant fish species in the Lower Volta mangrove swamps 
niloticus dominated constituting $22.2 \%$ of the catch. Other species of importance were Clarias sp. $14.6 \%$, L. falcipinnis $10.4 \%$, S. melanotheron $8.6 \%$ and C. nigrodigitatus $7.6 \%$.

Figure 3 shows fish composition by family in terms of abundance and weight respectively. Considering abundance in the whole area, Mugilidae dominated (31.0\%) followed by Gerreidae (20.0\%). The dominance of families however, differed from station to station. For example, Gerreidae dominated the catch at Station 1, Clupeidae at Station 2, Bothidae at Station 3, Mugilidae at Station 4, and Cichlidae at Stations 5, 6 and 7. In terms of weight Mugilidae again dominated followed by Osteoglossidae. They constituted 27.0 and $22.0 \%$ respectively of the total catch in the whole area. While the former was found at all the stations the latter, a freshwater species, was confined to only Station 7.

\section{Forage Carnivore $(F / C)$ ratio}

The ecological balance of the fish population, as measured by the Forage-Carnivore (F/C) ratio, using number, are shown in Table 2 for the Stations indicated. With the exception of Station 1, the F/C ratios for the other Stations fell within the recommended range of 1.4 and 10 indicating an ecologically balanced fish community.
Table 2 F/C ratios of the fish communities sampled at the various sites in the Lower Volta Mangrove swamps

\begin{tabular}{ll}
\hline Station & F/C ratio \\
\hline 1 & 29.6 \\
$2 * * *$ & 2.14 \\
$3 * *$ & 4.06 \\
$4 *$ & 1.66 \\
7 & 1.56 \\
Whole area & 4.68 \\
\hline
\end{tabular}

* Extent of mangroove cover

\section{Length-Frequency Distribution}

The length-frequency histograms (Fig 4) for some commonly occurring species during the study period emphasised that most of the populations, during the period, consisted of juvenile fish. The contribution of juvenile fishes to the length frequency histograms was at least $70 \%$ for most of the species except for Porogobius schlegelii which, by nature, is a small-sized fish. Even though the length frequency of Sarotherodon melanotheron showed a high proportion of small-sized fishes, most of the females were mature with eggs.
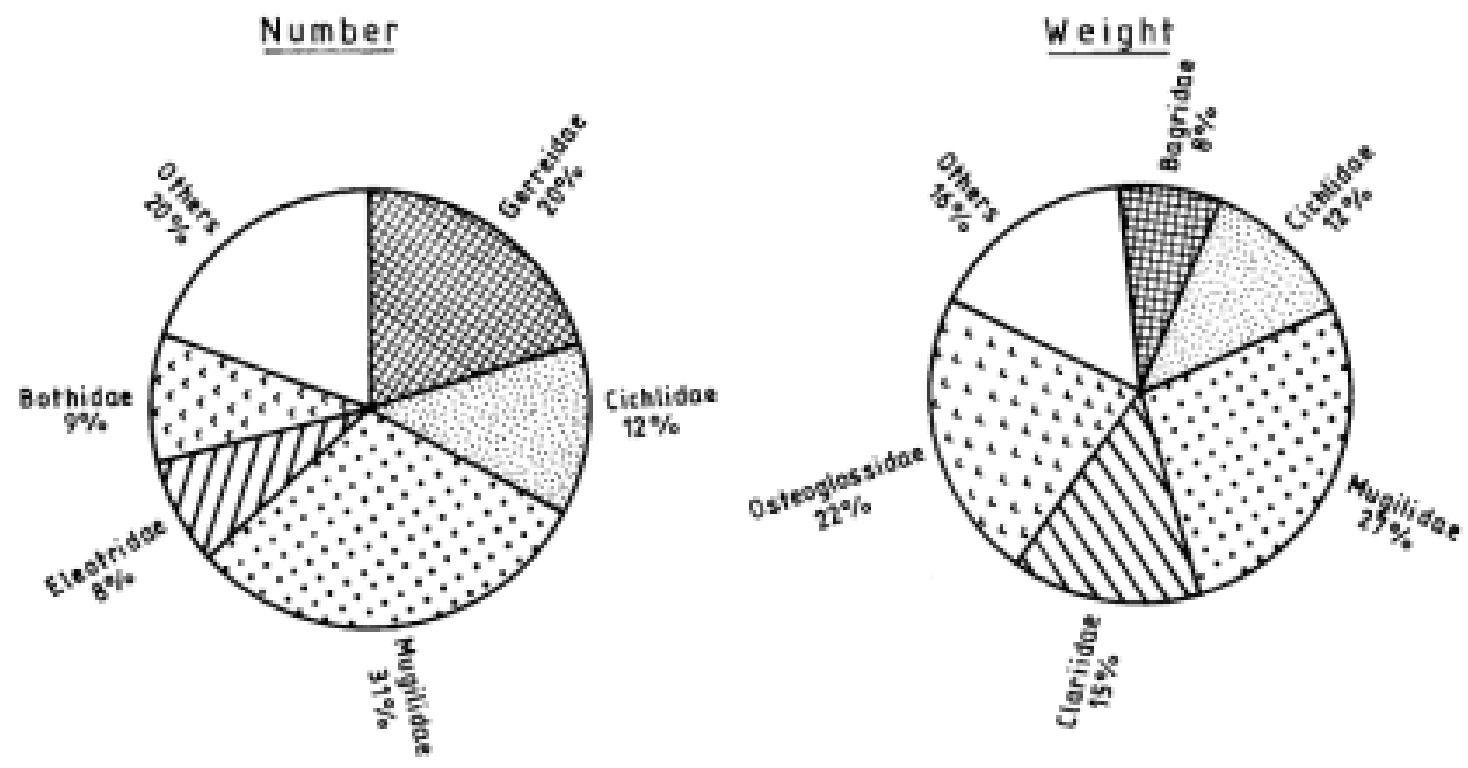

Fig. 3: Percentage composition of most dominant fish families in the Lower Volta mangrove swamps 


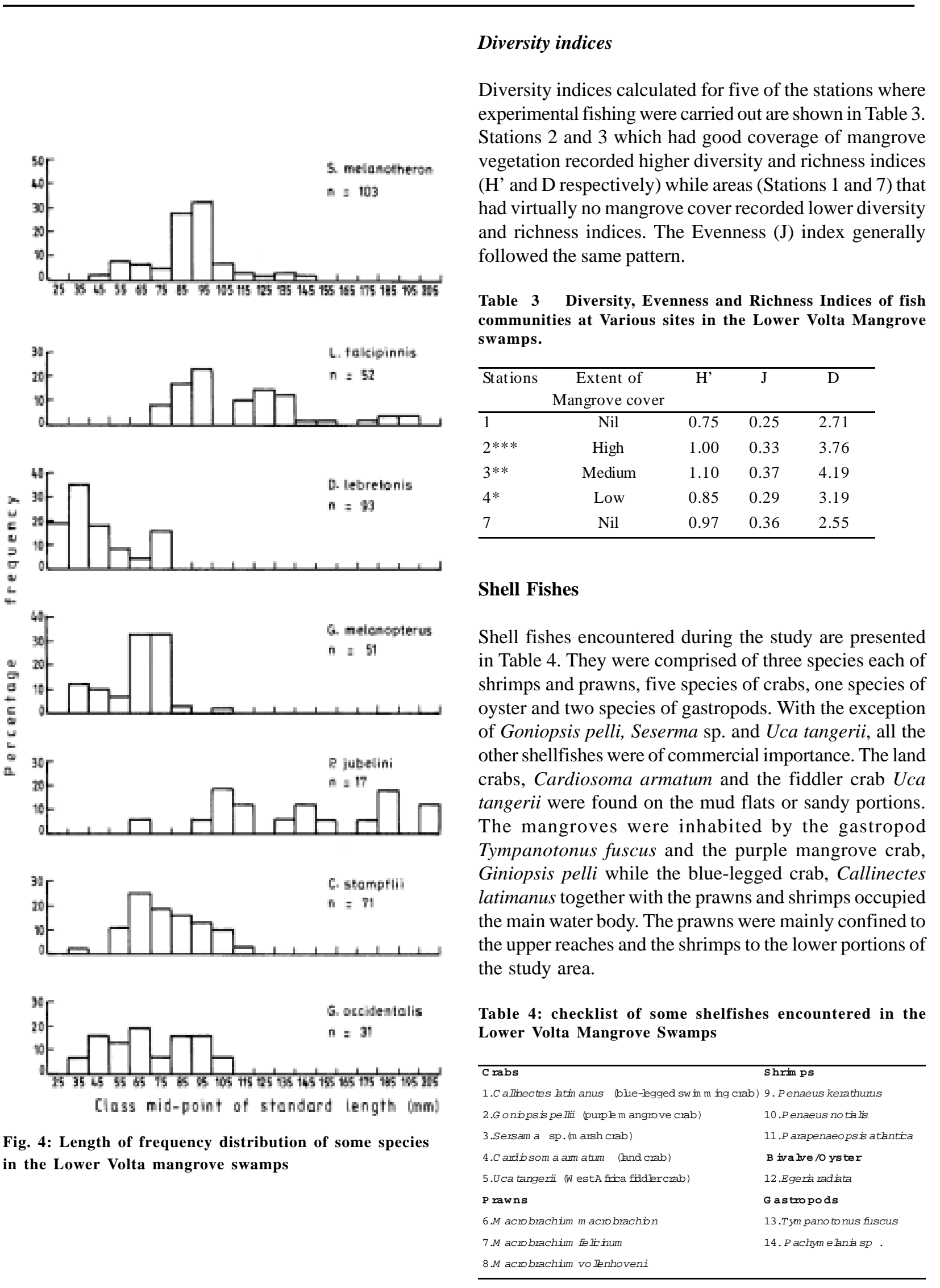




\section{Fishing gears and methods}

Fishing gears employed in the study area were gill nets, basket traps (for trapping both fish and crabs - Callinectes sp.), traps made of empty tins (mainly for trapping Cardiosoma sp.), hook and line and 'hatsi'. 'Hatsi' is the local name for a $\mathrm{V}$-shaped enclosure made of netting material and enforced with sticks or branches erected within the water body where flow was fairly fast. This was effective for catching shrimps and prawns. Other gears included cast net, seine/drag net, spear or harpoon and lift nets. Apart from these gears other methods used were the 'acadja' system or brush park and bailing of water from 'mud-built' enclosures used for fishing especially, within the mangrove vegetation.

\section{DISCUSSION}

Marine species constituted $52.6 \%$ of the total number of species caught while brackish and freshwater species constituted 26.3 and $21.1 \%$ respectively. Boaden and Seed (1993) have reported the dominance of marine species in estuaries and attributed it to the presence of both euryhaline and stenohaline species in the marine environment. The smaller number of brackish water species was to be expected since only a few species have been able to evolve the necessary physiological mechanisms to tolerate the highly unstable and stressful conditions that prevail in estuaries (Boaden and Seed, 1993). This may explain the wider distribution of brackish water species in the study area.

With the exception of some few species e.g., $C$. nigrodigitatus, marine and fresh water species were generally confined to the lower and upper reaches of the study area respectively. The longitudinal distribution of C. nigrodigitatus, a fresh water classified species, is known to stretch from lower to near upper reaches of rivers in West Africa (Teugels and Thys, 1992). Its ability to tolerate wide range of salinity has made it a good candidate for brackish water culture. The other brackish water species, Mugil spp. and T. guineensis, can also accommodate fresh waters hence their occurrence in the upper reaches of the study area.

Generally, the marine species encountered in the estuary were mostly juveniles, as indicated by the length-frequency distribution, and could be considered as temporary visitors who utilised the area as feeding and nursery grounds. They may therefore not be found in the study area on regular basis. Food availability and shelter from predators have been stated amongst the possible reasons why higher proportions of juvenile fishes are found in estuaries (John and Lawson, 1990; Robertson and Duke, 1987; Boesch and Turner, 1984; Shenker and Dean, 1979; Weistein, 1979). The comparatively higher diversity indices recorded at stations with extensive mangrove cover emphasis this assertion since the complex nature of the mangrove habitat, is likely to offer better refuge and most probably more food resource for a variety of fishes.

Fish and fishing related activities were among the main occupation of the majority of the people in the communities. Fish was also the main source of animal protein, and therefore, played a vital role in the socio-economic life of the people. With the exception of Periophthalmus papilio, Tetraodon lineatus., Seserma sp. and Goniopsis sp., all the other species were of high food value. P. papilio and $T$. lineatus are however of economic value as aquarium fishes. Even though the crabs, Seserma sp. and Goniopsis sp., were not economically important as food or aquarium species, they play a very important role in the ecosystem as part of the macrofauna, by helping in the breakdown of decaying organic matter (Chong, et al., 1990). They were also used as baits for trapping Callinectes sp.

Active fishing was mostly done by men while fish processing and marketing was the preserve of women who either, salted, dried, smoked or fried the fish depending on the type of species. The cichlids, especially tilapia, were either salted or dried while small-sized species e.g., $P$. schlegelii, D. lebretonis, P. leonensis, were either dried or fried. In addition to processing and marketing, it was not uncommon to find women in active fishing especially, for the oyster Egeria sp. and the gastropod, Tympanotonus $\mathrm{sp}$. The latter were hand-picked with the help of children from the mangrove and intertidal areas and bagged in fertiliser sacs for 'export' to the Central and Western regions of the country. A $50 \mathrm{~kg}$ fertiliser sac full of Tympanotonus cost about $\$ 2.22$. Oysters were also harvested by diving and picking them from the riverbed.

There were a good number of people, especially, the old men who earned their living through the construction or weaving of the various traps used for fish and crabs. These traps were woven from local materials and one could cost about $\$ 0.89$ to $\$ 2.22$ depending on the type and size. The average daily income of a full-time fishermen was estimated between $\$ 2.22$ and $\$ 3.82$ which was more than the current Government approved daily minimum wage of $\$ 0.89$. A conservative estimate made from average daily landings and from the estimated number of fishermen indicated that current fish yield from the area was between $450-500 \mathrm{Mt}$ $\mathrm{yr}^{-1}$ costing between $\phi 900$ million and $\phi 1$ billion annually (US\$400,000-450,000). 
Even though there were no long-term records of catches from the area, the general perception among fishermen was that fish catches have declined considerably. This was attributed to the construction of the dam on the Volta River at Akosombo, which was closed in 1964. The construction of the dam has resulted in periodic build up of sand bar at the estuary, which limits seawater incursions and consequently restricts larval forms and marine fish species that, even temporarily, populate the estuary during high tides. The limitation of seawater incursions has also reduced the longitudinal distribution of brackish and marine water species (both shell and fin). This was clearly demonstrated by the distribution of shrimps and oysters in the estuary. Observations and interviews conducted as well as previous studies (Attipoe and Amoah, 1985) indicated that several areas, hitherto, occupied by certain species have been deserted due to changes in the water regime. The absence of seasonal floods, with its associated changes in water quality, which act as a stimulant for some species to migrate upstream to spawn has also affected fish yield in the area. Flood plains, which provide food and refuge for juvenile fishes, are no more created because of the construction of the dam.

Another important factor that was found to militate against fish production, which the fishermen had not considered or were not aware of, was the destruction of mangrove cover either for fuel wood or for construction purposes. Mangrove cover increases the diversity and complexity of estuarine systems within which juvenile fishes take refuge and avoid predation. The root system and stem serve as areas or points of attachment for the growth of periphyton, zooplankton and other organisms, which serve as food for fish. The continuous removal of mangrove is likely to reduce litter production, which is the basis for detrital food chain upon which most fishes depend. Mac Nae (1974) and Sasekumar and Chong (1987) have established the correlation between fish and shrimp yields and the area of mangrove cover. The decline in the fishery of the Tonk Sap of the Mekong river has been traced largely to the removal of the old flooded forest on its shore (Welcomme, 1992). Other factors include the use of illegal fishing gears and methods.

\section{CONCLUSIONS}

The most dominant species in the mangrove swamps were G. melanopterus, S. melanotheron, C. anguillaris, L. falcipinnis and $M$. curema. The mangrove swamps served as an important nursery area for most of the species. The use of unauthorised fishing methods, spread of aquatic weeds and the destruction of mangrove vegetation pose a great threat to the fisheries in the area. The mangrove estuarine fisheries played a significant role in the economic life of the communities therefore; any reduction in the fisheries resources resulting from mismanagement will adversely affect them. In much the same way any meaningful development of the mangrove fisheries will go a long way to help sustain the riparian communities.

\section{RECOMMENDATIONS}

Regulation on the use of net mesh size should be enforced to ensure that juvenile fishes are not harvested along side adult ones. This will allow the nursery potential of the area to be fully realised. There is also the need to control the spread of aquatic weeds by the various communities in their respective areas with the help of Local Authorities, District Assemblies and Assemblymen. To ensure a more efficient way of utilizing fuel wood the "Chorkor" smoker should be introduced in the area. Fuel wood plantations or replanting of mangrove either on community or individual basis should be encouraged to take some of the pressure off from the natural mangrove stands. There should be regular but controlled breaching of the sand bar at the mouth of the estuary to allow the influx of more marine water to help repopulate the area with more marine species on regular basis. Fisheries enhancement should be encouraged in small enclosed water bodies and lagoons with $S$. melanotheron and mullet species which already exist in the area.

\section{ACKNOWLEDGEMENTS}

Funding for the Lower Volta Mangrove Project was provided by the Department for International Development (DFID) - U.K. The authors are grateful to Messrs Nicholas Anawoe and S.A Agbenyo and all those who assisted in the field. The contributions made by Dr. E.K. Abban is greatly acknowledged.

\section{REFERENCES}

Attipoe, Y.K. and Amoah, C. (1989). Ecological problems associated with the Volta Dams: The case of Egeria and Macrobrachium fisheries of the Lower Volta. IAB Mimeo 20 pp.

Bailey, C. (1988). The social consequences of tropical shrimp mariculture development. Ocean and Shoreline Management 11, 31-44.

Boaden, P.J.S. and Seed, R. (1993). An introduction to coastal ecology. Chapman and Hall, London 218pp.

Boech, D.F. and Turner, R.E. (1984). Dependence of fishery species on salt marshes: The role of food and refuge. Estuaries 7, 460-468. 
Brusher, H.A. (1994). The magnitude, distribution and availability of prawn (Penaeidae) resources in coastal and estuaries of Kenya. J. Mar. Biol. Ass. India 16, 335-348.

Chong, V.C., Sasekumar, M.U.C. and Cruz, R.D. (1990). The fish and prawn communities of Malaysian Coastal Mangrove Systems, with comparisons to adjacent mudflats and inshore waters. Estuarine, Coastal and Shelf Science 31, 703-722.

Laevastu, T. (1965). Manual methods in fisheries biology. FAO, Rome.

John, D.M. and Lawson, G.W. (1990). A review of mangrove and coastal ecosystems in West Africa and their possible relationships. Estuarine, Coastal and Shelf Science 31, 505-518.

Lévêque, C., Paugy, D. and Teugels, G.G. (1990). Faune des poissons déus dauces et saumâtre d'Afrique de l'Ouest. Vol. I. Faune Tropical no. XXVIII.

Lévêque, C., Paugy, D. and Teugels, G.G. (1992). Faune des poissons déus dauces et saumâtre d'Afrique de l'Ouest. Vol. II Faune Tropical no. XXVIII.

Mac Nae, W. (1974). Mangrove forests and fisheries. Indian Ocean Programme. Indian Ocean Fisheries Commission Roma, IOFC/DEV/74/34.

McHugh, J.L. (1966). Management of estuarine fishes. Am. Fish. Soc. Spec. Publ. 3, 133-154.

Margalef, R. (1968). Perspectives in ecological theory. University of Chicago Press, Chicago. 111pp.

Pielou, E.C. (1969). An introduction to mathematical ecology. John Wiley \& Sons, New York.

Robertson, A.I. (1986). Leaf burying crabs: their influence on energy flow and export from mixed mangrove forests (Rhizophora spp.) in northern Australia. $J$. Mar. Biol. Ecol. 102, 237-248.

Robertson, A.I and Duke, N.C. (1987). Mangroves as nursery sites; comparisons of the abundance and species composition of fish and crustaceans in mangroves and other nearshore habitats in Tropical Australia. Mar. Biol. 96, 193-205.

Sasekumar, A., Chong, V.C., Leh, M.U. and D'Cruz, R. (1992). Mangroves as a habitat for fish and prawns. Hydrobiologia 247, 195-207.

Sasekumar, A. and Chong, V.C (1987). "Mangroves and prawns; further perspectives". In: Sasekumar, et al., (Eds.), Proceedings of the $10^{\text {th }}$ Annual Seminar of the Malaysian Society of Marine Sciences University of Malay, Kuala Lumpur, Malaysia.pp.10-22.

Schneider, W. (1990). Field guide to the commercial marine resources of the Gulf of Guinea. RAFR/FI/90/2. FAO, Rome. 268pp.
Singh, T. (1987). The use of mangrove-managed areas for aquaculture. Workshop on the conversion of mangrove areas to Aquaculture. UNDP/UNESCO Regional Project RAS/79/002.

Shannon, C.E. and Weaver, W. (1963). The Mathematical Theory of Communication. University of Illinois Press, Urbana, 117pp.

Shenker, J.M. and Dean, J.M. (1979). The utilisation of intertidal salt marsh creek by larval and juvenile fishes; abundance, diversity and temporal variations. Estuaries 2, 154-163.

Teugels, G.G. and Thys van den Audenaerde, D.F.E, (1992). Cichlidae, in C.Lévêque, D. Paugy, and G.G. Teugels (eds.), Faune des poissons d'eaux douces et saumâtres de l'Afrique de O'uest. Tomme 2. Coll. Faune Tropical Trop. 28. ORSTOM, Paris and MRAC, Trevuren p.714-779.

Turner, R.E. (1977). Intertidal vegetation and commercial yields of penaeid shrimp. Trans. Am. Fish Soc. 106, 411-416.

Weistein, M.P. (1979). Shallow marsh habitat as primary nurseries of fishes and shellfish, Cape Fear River, North Carolina. Fishery Bulletin US 77, 339-357.

Welcomme, R.L. (1992). The conservation and environmental management of fishes in inland and coastal waters. Netherlands Journal of Zoology 42(22), 186-189. 